\title{
BANGKA TENGAH
}

\author{
Abdul Sani \\ saniabdul30@gmail.com \\ BKPSDM Provinsi Kepulauan Bangka Belitung
}

\section{ABSTRAK}

Pemerintah didalam menyelenggarakan pelayanan publik masih banyak dijumpai kekurangan sehingga jika dilihat dari segi kualitas belum seperti yang diharapkan masyarakat. Masih ditemukannya berbagai keluhan masyarakat mengenai pelayanan langsung yang diberikan pemerintah. Keluhan ini dapat dirasakan dan dilihat langsung ketika berada ditempat pelayanan maupun keluhan dan tanggapan masyarakat melalui media. Kualitas pelayanan pemerintah secara umum masih jauh dari memenuhi harapan masyarakat, tidak terkecuali di Poliklinik Gigi RSUD Bangka Tengah. Penelitian ini bertujuan untuk menganalisis kualitas pelayanan publik di Poliklinik tersebut. Pisau Analisis yang digunakan adalah Teori ServQual dari Parasuraman, Berry dan Zethitamal. Metode penelitian yang digunakan adalah metode deskriptif pendekatan kualitatif. Teknik Pengumpulan Data penelitian ini menggunakan kuesioner, observasi, wawancara dan dokumentasi yang diperoleh di lokasi penelitian dengan informan yang berasal baik dari internal maupun eksternal RSUD. Hasil penelitian menunjukkan bahwa dimensi Assurance (jaminan) dinilai cukup berkualitas, dimensi Responsivenes (ketanggapan) dinilai berkualitas dan Emphaty (empati) dinilai cukup berkualitas.

Kata Kunci: Kualitas, Pelayanan, Publik

\section{ABSTRACT}

The Government in organizing public services are still many shortcomings so seen in terms of quality not as expected by the community. There are still found public complaints regarding the direct services provided by the government. This complaint can be felt and seen immediately when in the service place and or through from media. The quality of government services in general is far from the expectations of the community, no exception at the Dental Polyclinic of Bangka Tengah regional public hospital. This Research aims to analize of the quality of public services at the installation. The analysis used is the ServQual Theory from Parasuraman, Berry and Zethitamal. This research data collection technique using questionnaires, observations, interviews and documentation obtained at the research location with informants from both internal and external Bangka Tengah regional hospital. The results of the research show that the dimensions of Responsiveness is assessed enough qualited, Assurance is assessed qualited and Emphaty is assessed enough qualited.

Keywords: Quality, Service, Public 


\section{PENDAHULUAN}

Era baru pelayanan publik menempatkan publik sebagai pengguna jasa dan pemerintah sebagai penyelenggara pelayanan. Sesuai dengan peran pemerintah sebagai pelayan masyarakat, maka pemerintah harus memantau dan memperhatikan kepuasan masyarakat sebagai pihak yang dilayani. Prinsip ini senada dengan esensi Undang-Undang No. 25 Tahun 2009 tentang Pelayanan Publik. Di dalam undangundang tersebut dinyatakan bahwa negara berkewajiban melayani setiap warga negara dan penduduk untuk memenuhi hak dan kebutuhan dasarnya dalam kerangka pelayanan publik yang merupakan amanat Undang-Undang Dasar Negara Republik Indonesia Tahun 1945, membangun kepercayaan masyarakat atas pelayanan publik yang dilakukan penyelenggara pelayanan publik merupakan kegiatan yang harus dilakukan seiring dengan harapan dan tuntutan seluruh warga negara dan penduduk tentang peningkatan pelayanan publik, sebagai upaya untuk mempertegas hak dan kewajiban setiap warga negara dan penduduk serta terwujudnya tanggung jawab negara dan korporasi dalam penyelenggaraan pelayanan publik, diperlukan norma hukum yang memberi pengaturan secara jelas, sebagai upaya untuk meningkatkan kualitas dan menjamin penyediaan pelayanan publik sesuai dengan asas-asas umum pemerintahan dan korporasi yang baik serta untuk memberi perlindungan bagi setiap warga negara dan penduduk dari penyalahgunaan wewenang di dalam penyelenggaraan pelayanan publik.

Tuntutan akan kualitas penyelenggaraan pelayanan dewasa ini dirasakan sangat meningkat. Masyarakat pada umumnya tidak dapat lagi dipenuhi kebutuhannya atas dasar standar pemerintah semata, malainkan telah dituntut adanya kualitas layanan yang ditentukan oleh kebutuhan masyarakatnya sendiri. Kebutuhan tersebut ditujukan baik terhadap barang privat (private goods) maupun terhadap barang publik (public goods). Barang layanan privat dapat dipenuhi melalui mekanisme pasar, sementara barang publik tidak dapat dipenuhi melalui mekanisme pasar melainkan harus melalui pengaturan yang dilakukan oleh pemerintah.

Pemerintah didalam menyelenggarakan pelayanan publik masih relatif banyak dijumpai kekurangan sehingga jika dilihat dari segi kualitas belum seperti yang diharapkan masyarakat. Masih munculnya berbagai keluhan masyarakat mengenai pelayanan langsung yang diberikan pemerintah. Keluhan ini dapat dirasakan dan dilihat langsung ketika berada ditempat pelayanan maupun keluhan dan tanggapan masyarakat melalui media. Jika keluhan-keluhan dari masyarakat tidak direspon oleh pemerintah maka akan menimbulkan citra yang kurang baik terhadap pemerintah sendiri.

Salah satu pelayanan publik yang perlu mendapat perhatian pemerintah adalah rumah sakit. Rumah Sakit merupakan salah satu sarana kesehatan yang menyelenggarakan kegiatan pelayanan kesehatan yang menjadi pilihan utama bagi masyarakat. Kegiatan pelayanan yang diberikan rumah sakit meliputi pelayanan kesehatan dasar, rujukan dan kesehatan penunjang dengan memperhatikan fungsi sosial. Kebutuhan akan kesehatan mempengaruhi masyarakat dalam memilih sarana kesehatan dimana masyarakat menginginkan pelayanan yang terbaik untuk dirinya. Salah satunya dengan memeriksakan dirinya ke rumah sakit. Persaingan bisnis rumah sakit saat ini semakin kompetitif sehingga mengubah cara berfikir masyarakat dalam memilih dan memberikan penilaian terhadap pelayanan kesehatan. Hal ini menjadi tuntutan bagi rumah sakit agar lebih memperhatikan dan meningkatkan pelayanan serta kepuasan terhadap pasien baik pasien rawat jalan maupun pasien rawat inap. Untuk mencapai hal tersebut rumah sakit harus bisa memanfaatkan sumber daya yang ada untuk digunakan dalam pencapaian tujuan terutama berkaitan dengan peningkatan kualitas pelayanan. Rumah sakit yang tidak berkualitas dalam memberikan pelayanan akan ketinggalan dan terlindas dalam persaingan bisnis.

Mengacu pada fungsi pelayanan, Rumah Sakit Umum Daerah (RSUD) Kabupaten Bangka Tengah sebagai salah satu pusat pelayanan kesehatan di Indonesia wajib untuk memberikan pelayanan yang optimal kepada masyarakat Bangka Tengah. Pelayanan yang diberikan berhubungan langsung kepada masyarakat. Dengan memberikan pelayanan yang baik maka akan berimbas pada penilaian dan persepsi publik terhadap kinerja RSUD Bangka Tengah.

RSUD Bangka Tengah merupakan salah satu rumah sakit yang ada di Indonesia. Rumah 
sakit ini adalah milik Pemerintah Daerah Kabupaten Bangka Tengah. Penilaian masyarakat

terhadap kinerja pelayanan publik di RSUD Bangka Tengah khususnya di Poliklinik Gigi pada Instalasi Rawat Jalan sendiri masih belum diketahui. Oleh karena itu, perlu adanya penelitian untuk membahas penilaian masyarakat terhadap kualitas pelayanan publik di tempat tersebut.

Berdasarkan penjelasan latar belakang di atas maka rumusan masalah dalam penelitian ini adalah "Bagaimanakah Kualitas Pelayanan Publik di Poliklinik Gigi RSUD Bangka Tengah ?"

\section{URAIAN PENELITIAN}

A. Kualitas Pelayanan

Kualitas pelayanan merupakan upaya pemerintah untuk menciptakan kepuasan bagi para pengguna pelayanan, jika pengguna pelayanan merasa puas dengan pelayanan yang telah diterima dapat disimpulkan bahwa pemerintah telah memberikan pelayanan yang sesuai degan tugas pemerintah. Kualitas pelayanan publik yang diberikan oleh pemerintah harus memperhatikan kepuasan dari penerima pelayanan.

1. Pengertian Kualitas Pelayanan

Menurut Tjiptono (1995) yang dikutip dalam Hardiyansyah (2011:40) kualitas pelayanan adalah: (1) Kesesuaian dengan persyaratan; (2) Kecocokan untuk pemakaian; (3) Perbaikan Bekelanjutan; (4)Bebas dari kerusakan/cacat; (5)Pemenuhan kebutuhan pelanggan sejak awal dan setiap saat; (6) Melakukan segala sesuatu secara benar; (7) sesuatu yang bisa membahagiakan pelanggan.

Melayani secara tepat dan memuaskan, berlaku sopan, ramah dan menolong serta profesional,

adalah standar kualitas pelayanan yang harus dicapai oleh seseorang/kelompok/lembaga/organis asi. Berkualitas mempunyai arti memuaskan pada yang dilayani, baik internal maupun eksternal dalam arti optimal atas pemenuhan atas tuntutan/persyaratan pelanggan masyarakat. Menurut Ibrahim dalam Hardiyansyah (2011:40), kualitas pelayanan publik merupakan suatu

kondisi dinamis yang berhubungan dengan produk, jasa, manusia, proses, dan lingkungan dimana penilaian kualitasnya ditentukan pada saat terjadi pemberian pelayanan publik tersebut.

Berdasarkan beberapa definisi kualitas pelayanan diatas dapat disimpulkan bahwa kualitas pelayanan adalah suatu kemampuan untuk menyesuiakan antara keinginan atau tuntutan penerima pelayanan dengan pelayanan yang diberikan oleh penyelenggara pelayanan berupa produk atau jasa sesuai dengan syarat yang telah ditentukan.

2. Indikator Kualitas Pelayanan

Pelayanan publik merupakan tuntutan masyarakat agar kebutuhan mereka baik secara individu maupun sebagai kelompok terpenuhi. Karena itu dituntut dari pemerinthan untuk meningkatkan kualitas pelayanan bagi masyarakat. Kualitas pelayanan publik yang diberikan oleh pemerintah harus memperhatikan kepuasan dari penerima pelayanan. Dalam rangka menilai sejauh mana kualitas pelayanan publik yang diberikan oleh aparatur pemerintah, perlu ada kriteria yang menunjukkan apakah suatu pelayanan publik yang diberikan dapat dikatakan baik atau buruk, berkualitas atau tidak. Berkenaan dengan hal tersebut, Zeithaml, Berry dan Parasuraman dalam Hardiansyah (2011:40) mengatakan bahwa:

SERVQUAL is an empirically derived method that may be used by a services organization to improve service quality. The method involves the development of an understanding of the perceived service needs of target customers. The resulting gap analysis may then be used as a driver for service quality 
improvement.

SERVQUAL merupakan metode yang diturunkan secara empiris yang

dapat digunakan oleh organisasi pelayanan untuk meningkatkan kualitas pelayanan. Metode ini meliputi pengembangan pemahaman mengenai kebutuhan layanan yang dirasakan oleh pelanggan. Hal ini diukur dari persepsi kualitas pelayanan bagi organisasi yang bersangkutan. Analisis kesenjangan yang dihasilkan kemudian dapat digunakan sebagai panduan untuk peningkatan kualitas layanan. Selanjutnya, Zeithaml, Berry dan Parasuraman dalam Hardiyansyah (2011:41) menyatakan bahwa kualitas pelayanan ditentukan oleh dua hal, yaitu:

$$
\text { “...expected service dan }
$$
perceived service. Expected service dan perceived ditentukan oleh dimention of service quality yang terdiri dari sepuluh dimensi, yaitu: (1) Tangibles. Appearance of physical facilities, equipment, personnel, and communication materials; (2) Reliability. Ability to perform the promised service dependably and accurately; (3) Responsiveness. Willingness to help customers and provide prompt service; (4) Competence. Possession of required skill and knowledge to perform service; (5) Courtesy. Politeness, respect, consideration and friendliness of contact personnel; (6) Credibility. Trustworthiness, believability, honestly of the service provider; (7) Feel Secure. Freedom from danger risk, or doubt; (8) Access. Approachable and easy of contact; (9) Communication. Listens to its customers and acknowledges their comments. Keeps customers informed. In a language which they can understand; and (10) Understanding the customer.
Making the effort to know customers and their needs"

Berdasarkan uraian di atas, Zeithaml dalam Hardiyansyah (2011:41) menjelaskan bahwa ukuran kualitas

pelayanan memiliki sepuluh dimensi, yaitu:

1) Tangibles (berwujud fisik), terdiri atas fasilitas fisik, peralatan, personil dan komunikasi;

2) Reliability (kehandalan), terdiri dari kemampuan unit pelayanan dalam menciptakan pelayanan yang dijanjikan dengan tepat;

3) Responsiveness (ketanggapan), kemauan untuk membantu konsumen, bertanggungjawab terhadap kualitas pelayanan yang diberikan;

4) Competence (kompeten), terdiri atas tuntutan yang dimilikinya, pengetahuan dan keterampilan yang baik oleh aparatur dalam memberikan pelayanan;

5) Courtesy (ramah), sikap atau perilaku ramah, bersahabat, tanggap terhadap keinginan konsumen serta mau melakukan kontak;

6) Credibility (dapat dipercaya), sikap jujur dalam setiap upaya untuk menarik kepercayaan masyarakat;

7) Security (merasa aman), jasa pelayanan yang diberikan harus bebas dari berbagai bahaya atau resiko;

8) Access (akses), terdapat kemudahan untuk mengadakan kontak dan pendekatan;

9) Communication (komunikasi), kemauan pemberi pelayanan untuk mendengarkan suara, keinginan atau aspirasi pelanggan;

10) Understanding the customer (memahami pelanggan), serta melakukan segala usaha untuk mengetahui kebutuhan pelanggan.

Berdasarkan sepuluh dimensi kualitas pelayanan tersebut, kemudian Zeithaml, Berry dan 
Parasuraman (1990) dalam Hardiyansyah (2011:42) menyederhanakan SERVQUAL (kualitas pelayanan) menjadi lima dimensi, yaitu:

1) Tangibles. Appearance of physical facilities, equipment, personnel, and communication materials;

(2) Reliability. Ability to perform the promised service dependably and accurately; (3) Responsiveness. Willingness to help customers and provide prompt service; (4) Assurance. Knowledge and courtesy of employees and their ability to convey trust and confidence; and (5) Empathy. The firm provides care and individualized attention to its customers.

Dari pendapat diatas dapat dipahami bahwa SERVQUAL ada lima dimensi yaitu: (1) tangibles, meliputi fasilitas fisik, perlengkapan, pegawai, dan sarana komunikasi; (2) realibility, yaitu kemampuan untuk memberikan pelayanan yang dijanjikan tepat waktu dan memuaskan; (3) responsiveness, kemampuan para staf untuk membantu para pelanggan dan memberikan pelayanan yang tanggap; (4) assurance, mencakup kemampuan, kesopanan, bebas dari bahaya resiko atau keraguan; (5) emphaty, yaitu mencakup kemudahan dalam melakukan hubungan komunikasi yang baik dan memahami kebutuhan para pelanggan. Untuk lebih jelasnya menurut Zeithaml, Berry dan Parasuraman (1990) dalam Hardiansyah (2011:41) menyatakan bahwa kualitas pelayanan dapat diukur dari 5 dimensi, yaitu: Tangible (Berwujud), Reliability (Kehandalan), Responsiveness (Ketanggapan), Assurance (Jaminan), dan Emphaty (Empati). Masing-masing dimensi memiliki indikator sebagai berikut:

1) Untuk dimensi Tangible (Berwujud), terdiri atas indikator:
a.Penampilan petugas/aparatur dalam melayani pelanggan
b.Kenyamanan tempat melakukan pelayanan

c. Kedisiplinan petugas/aparatur dalam melakukan pelayanan

d.Kemudahan proses dan akses layanan

e.Penggunaan alat bantu dalam pelayanan

2) Untuk dimensi Reliability (Kehandalan), terdiri atas indikator:

a. Kecermatan petugas dalam melayani pelanggan

b.Memiliki standar pelayanan yang jelas

c. Kemampuan petugas/aparatur dalam menggunakan alat bantu dalam proses pelayanan

d.Keahlian petugas dalam menggunakan alat bantu dalam proses pelayanan

3) Untuk dimensi Responsiveness (Respon/Ketanggapan), terdiri atas indikator:

a.Merespon setiap pelanggan/ pemohon yang ingin mendapatkan pelayanan

b.Petugas/aparatur melakukan pelayanan dengan cepat dan tepat

c.Petugas/aparatur melakukan pelayanan dengan cermat

d.Semua keluhan pelanggan direspon oleh petugas

4) Untuk dimensi Assurance (Jaminan), terdiri atas indikator:

a.Petugas memberikan jaminan tepat waktu dalam pelayanan

b.Petugas memberikan jaminan legalitas dalam pelayanan

c.Petugas memberikan jaminan kepastian biaya dalam pelayanan

5) Untuk dimensi Emphaty (Empati), terdiri atas indikator:

a. Mendahulukan kepentingan pemohon/pelanggan

b.Petugas melayani dengan sikap ramah

c. Petugas melayani dengan sikap sopan santun 
d.Petugas melayani dengan tidak diskriminatif (membedabedakan)

e.Petugas melayani dan menghargai setiap pelanggan

Penilaian terhadap kualitas pelayanan dengan model SERVQUAL

dilakukan dengan cara membandingkan harapan dan kenyataan pelayanan yang diterima masyarakat. Jika kenyataannya besar dan harapan kecil maka pelayanannya dianggap berkualitas. Namun sebaliknya jika kenyataannya kecil dan harapannya besar maka pelayanannya dianggap tidak berkualitas. Berdasarkan uraian di atas, ada beberapa teori yang berhubungan dengan kualitas pelayanan. Namun peneliti memilih teori dan ukuran atau dimensi kualitas pelayanan SERVQUAL yang dikemukakan oleh Zeithaml, Berry dan Parasuraman. Dalam penelitian ini peneliti hanya memfokuskan pada Responsiveness (Respon/Ketanggapan), Assurance (Jaminan) dan Emphaty (Empati). Menurut peneliti, bahwa ketiga dimensi kualitas pelayanan tersebut sangat relevan untuk dijadikan dimensi dan indikator dalam penelitian ini, karena dalam konsepnya ia mengatakan bahwa metode SERVQUAL (Service Quality) tersebut dapat digunakan dan dapat diterapkan pada semua tipe pelayanan dari berbagai organisasi, baik organisasi yang berorientasi laba maupun nirlaba, termasuk pelayanan publik di Poliklinik Gigi RSUD Bangka Tengah.

\section{METODE PENELITIAN}

Berdasarkan permasalahan yang dikemukakan di atas, maka Metode penelitian ini menggunakan metode deskriptif dengan pendekatan kualitatif. mendiskripsikan data yang diperoleh dari hasil penelitian mengenai analisis Kualitas Pelayanan Publik di Poliklinik Gigi Rumah Sakit Umum Daerah (RSUD) Bangka Tengah. Data dihimpun dengan pengamatan yang seksama, mencangkup deskripsi dalam konteks

yang mendetil. Penelitian ini dilakukan terhadap masyarakat pengguna pelayanan untuk menilai bagaimana kualitas pelayanan publik di Poliklinik Gigi pada RSUD Bangka Tengah. Kualitas pelayanan dapat dilihat berdasarkan hasil analisis kulaitas pelayanan itu sendiri.

Dalam hal penelitian kualitatif, Cresswell (2012) (dalam Sugiyono, 2014: 228) menyatakan bahwa penelitian kualitatif berarti proses eksplorasi dan memahami makna perilaku individu dan kelompok, menggambarkan masalah sosial atau masalah kemanusiaan. Proses penelitian mencakup membuat pertanyaan penelitian dan prosedur yang masih bersifat sementara, mengumpulkan data pada seting partisipan, analisis data secara induktif, membangun data yang parsial dalam tema, dan selanjutnya memberikan interpretasi terhadap makna suatu data. Kegiatan terakhir adalah membuat laporan ke dalam struktur yang fleksibel.

\section{HASIL PENELITIAN DAN PEMBAHASAN}

Berbagai macam penilaian masyarakat terhadap kualitas pelayanan publik saat ini. Penilaian masyarakat terhadap kualitas pelayanan publik di Poliklinik Gigi RSUD Bangka Tengah dapat diukur dengan menggunakan teori Servqual, yaitu Responsiveness (Ketanggapan), Assurance (Jaminan), dan Emphaty (Empati).

Masyarakat pengguna pelayanan publik akan menilai melalui kuesioner bagaimana penyelenggaraan pelayanan publik di Poliklinik Gigi RSUD Bangka Tengah dengan mengacu pada tiga dimensi kualitas pelayanan publik. Adapun pada kuesioner terdapat indikator yang memiliki bobot penilaian sebagai berikut:

a. Untuk jawaban yang sangat berkualitas diberi skor 5 .

b. Untuk jawaban yang berkualitas diberi skor 4.

c. Untuk jawaban yang cukup berkualitas diberi skor 3 .

d. Untuk jawaban yang tidak berkualitas diberi skor 2

e. Untuk jawaban yang sangat tidak berkualitas diberi skor 1

Adapun indikator kualitas pelayanan yang dinilai sebagai berikut:

a. Responsivenes: adalah keinginan untuk membantu para pemohon pelayanan dan memberikan pelayanan dengan cepat.

b. Assurance: adalah pengetahuan dan sopan santun para pegawai pemberi pelayanan, dan kemampuannya untuk 
memberikan kepercayaan dan keyakinan kepada para pemohon pelayanan.

c. Empathy: adalah memberikan perhatian penuh terhadap para pemohon pelayanan atau memberikan perhatian yang tulus

tanpa pamrih terhadap para pemohon pelayanan.

Hasil penilaian responden dan wawancara mendalam serta pembahasan untuk masingmasing dimensi servqual sebagai berikut:

a. Dimensi Responsivenes (kehandalan), yaitu keinginan untuk membantu para pemohon pelayanan dan memberikan pelayanan dengan cepat.

Hasil penilaian responden sebagaimana tersaji dalam tabel I

\section{Tabel I}

Tabel Frekuensi Kualitas Pelayanan dimensi Responsivness (Ketanggapan)

$$
\mathrm{n}=30
$$

\begin{tabular}{|c|c|c|c|c|c|c|c|c|c|c|}
\hline \multirow{2}{*}{ No } & \multirow{2}{*}{ Indikator } & \multicolumn{5}{|c|}{ Penilaian } & \multirow{2}{*}{ Jumlah } & \multirow{2}{*}{$\begin{array}{l}\text { Rata- } \\
\text { rata }\end{array}$} & \multirow{2}{*}{$\%$} & \multirow{2}{*}{ Keterangan } \\
\hline & & 1 & 2 & 3 & 4 & 5 & & & & \\
\hline 1 & $\begin{array}{l}\text { Pegawai yang memberikan pelayanan } \\
\text { kepada masyarakat harus tanggap dan } \\
\text { siap membantu bila pemohon pelayanan } \\
\text { mengalami kesulitan }\end{array}$ & 1 & 4 & 30 & 40 & 30 & 105 & 3.50 & 70.0 & Berkualitas \\
\hline 2 & $\begin{array}{l}\text { Pegawai yang memberikan pelayanan } \\
\text { harus proaktif }\end{array}$ & 0 & 6 & 27 & 40 & 35 & 108 & 3.60 & 72.0 & Berkualitas \\
\hline 3 & $\begin{array}{l}\text { Pegawai yang memberikan pelayanan } \\
\text { harus cepat dalam menangani dan } \\
\text { melayani serta menyelesaikan keluhan } \\
\text { pemohon pelayanan }\end{array}$ & 1 & 6 & 39 & 16 & 40 & 102 & 3.40 & 68.0 & $\begin{array}{l}\text { Cukup } \\
\text { Berkualitas }\end{array}$ \\
\hline 4 & $\begin{array}{l}\text { Instansi yang memberikan pelayanan } \\
\text { kepada masyarakat apabila melakukan } \\
\text { kesalahan harus segera memperbaikinya } \\
\text { dan meminta maaf kepada pemohon } \\
\text { pelayanan }\end{array}$ & 3 & 10 & 27 & 24 & 40 & 104 & 3.47 & 69.3 & $\begin{array}{c}\text { Cukup } \\
\text { Berkualitas }\end{array}$ \\
\hline & Nilai Rata-rata & & & & & & & 3.49 & 69.8 & $\begin{array}{c}\text { Cukup } \\
\text { Berkualitas }\end{array}$ \\
\hline
\end{tabular}

Sumber: Hasil pengolahan data primer

Dari tabel diatas menunjukkan bahwa nilai rata-rata dimensi Responsivness (Ketanggapan) adalah 3.49. Ini menunjukkan bahwa hasil kuesioner menyatakan penilaian responden terhadap dimensi ini adalah cukup berkualitas, atau sebanyak $69.8 \%$ responden menilai dimensi ini cukup berkualitas.

Dari hasil wawancara yang berasal dari informan internal dapat ditarik kesimpulan bahwa secara umum mereka menilai dimensi responsivness (ketanggapan) adalah berkualitas. Semua indikator pada dimensi ini dinilai berkualitas seperti pegawai harus memberikan perhatian, pegawai harus tanggap dan proaktif dalam melayani, cepat dalam melayani, meminta maaf bila melakukan kesalahan. Dalam arti kata sudah sesuai dengan Standar Pelayanan Minimal (SPM) dan Standar Operasional Prosedur (SOP) RSUD Bangka Tengah, serta sesuai dengan prinsip-prinsip pelayanan publik.

$$
\text { Adapun hasil wawancara }
$$


mendalam (in-depth interview) dengan pasien/keluarga pasien sebagai informan kunci (key informan) yang berjumlah tujuh orang mengenai dimensi Reliability (Kehandalana) adalah cukup berkualitas. Semua indikator dinilai cukup berkualitas. Seperti pegawai harus memberikan perhatian, pegawai harus I

tanggap dan proaktif dalam melayani, cepat dalam melayani, meminta maaf bila melakukan kesalahan. Dalam arti kata belum memuaskan dan masih perlu ditingkatkan lagi.

Dari hasil kuesioner dan wawancara mendalam (indepth-interview) dengan para informan baik informan kunci (key informan) maupun informan dari internal RSUD Bangka Tengah menilai dimensi responsiveness (ketanggapan) adalah cukup berkualitas. Sebagian besar informan menilai dimensi ini cukup berkualitas dan sebagian kecil menilai tidak berkualitas, terutama pada indikator ketanggapan dan kecepatan petugas dalam melayani pasien dirasakan masih perlu ditingkatkan. Dalam arti kata belum sesuai dengan Standar Pelayanan Minimal yang ditetapkan oleh Menteri Kesehatan melalui Peraturan Menteri
Kesehatan nomor 43 tahun 2016 serta Peraturan Bupati Bangka Tengah tentang Standar Pelayanan Minimal (SPM) RSUD Bangka Tengah tahun 2017 dan Standar Operasional Prosedur (SOP) yang ada. Namun secara umum menilai dimensi ini cukup berkualitas.

b. Dimensi Assurance (jaminan), yaitu pengetahuan dan sopan santun para pegawai pemberi pelayanan, dan kemampuannya untuk memberikan kepercayaan dan keyakinan kepada para pemohon pelayanan.

Adapun hasil penilaian responden sebagaimana tersaji dalam tabel II

\section{Tabel II}

Tabel Frekuensi Kualitas Pelayanan Dimensi Assurance (jaminan)

$$
\mathrm{n}=30
$$

\begin{tabular}{|c|c|c|c|c|c|c|c|c|c|c|}
\hline \multirow{2}{*}{ No } & \multirow{2}{*}{ Indikator } & \multicolumn{5}{|c|}{ Penilaian } & \multirow{2}{*}{ Jumlah } & \multirow{2}{*}{$\begin{array}{c}\text { Rata- } \\
\text { rata }\end{array}$} & \multirow{2}{*}{$\%$} & \multirow{2}{*}{ Keterangan } \\
\hline & & 1 & 2 & 3 & 4 & 5 & & & & \\
\hline 1 & $\begin{array}{l}\text { Instansi yang memberikan pelayanan } \\
\text { kepada masyarakat harus mampu } \\
\text { memberikan rasa aman dan nyaman }\end{array}$ & 0 & 6 & 33 & 28 & 45 & 112 & 3.73 & 74.67 & Berkualitas \\
\hline 2 & $\begin{array}{l}\text { Instansi yang memberikan pelayanan } \\
\text { kepada masyarakat harus mampu } \\
\text { memberikan kepercayaan dan } \\
\text { keyakinan kepada pemohon pelayanan, } \\
\text { bahwa di instansi ini bebas dari } \\
\text { percaloan dan pungutan liar }\end{array}$ & 0 & 10 & 18 & 28 & 60 & 116 & 3.87 & 77.33 & Berkualitas \\
\hline 3 & $\begin{array}{l}\text { Pegawai yang memberikan pelayanan } \\
\text { kepada msyarakat harus menguasai } \\
\text { setiap pertanyaan pemohon pelayanan }\end{array}$ & 0 & 6 & 27 & 32 & 50 & 115 & 3.83 & 76.67 & Berkualitas \\
\hline 4 & $\begin{array}{l}\text { Peugas memberikan keterangan yang } \\
\text { jelas terhadap pasien }\end{array}$ & 0 & 8 & 24 & 36 & 45 & 113 & 3.77 & 75.33 & Berkualitas \\
\hline
\end{tabular}


Dari tabel diatas menunjukkan bahwa nilai rata-rata dimensi assurance (jaminan) adalah 3.81. Ini menunjukkan bahwa hasil kuesioner menyatakan penilaian responden terhadap dimensi ini adalah berkualitas, atau sebanyak $76 \%$ responden menilai dimensi ini berkualitas.

Dari hasil wawancara yang berasal dari informan internal dapat

ditarik kesimpulan bahwa secara umum mereka menilai dimensi assurance (jaminan) adalah berkualitas. Semua indikator pada dimensi ini dinilai berkualitas seperti instansi yang memberikan pelayanan kepada masyarakat harus mampu memberikan rasa aman dan nyaman, pegawai yang

memberikan pelayanan kepada msyarakat harus menguasai setiap pertanyaan pemohon pelayanan, dan peugas memberikan keterangan yang jelas terhadap pasien. Instansi dan para petugas telah menjalankan tugasnya sesuai dengan Standar Pelayanan Minimal (SPM) dan Standar Operasional Prosedur (SOP) RSUD Bangka Tengah, serta sesuai dengan prinsip-prinsip pelayanan publik.

Adapun hasil wawancara mendalam (in-depth interview) dengan pasien/keluarga pasien sebagai informan kunci (key informan) yang berjumlah tujuh orang mengenai dimensi assurance (jaminan) inilai cukup berkualitas. Indikator yang dinilai kurang berkualitas adalah tentang jaminan instansi terhadap pungutan liar. Karena informan 7 merasakan tidak adanya sosialisasi

tentang pungutan liar.

Dari hasil kuesioner dan wawancara mendalam (indepth-interview) terhadap para informan baik informan kunci (key informan) maupun informan

dari internal RSUD Bangka Tengah dapat disimpulkan bahwa dimensi assurance (jaminan) dinilai berkualitas, terutama yang berkaitan dengan indikator tentang jaminan tidak ada pungutan liar. Dimana para informan menilai bahwa instansi RSUD bangka Tengah khususnya dibagian Poliklinik Gigi tidak menemukan adanya pungutan liar.

c. Analisis kualitas pelayanan publik di RSUD Bangka Tengah dimensi Empathy yaitu memberikan perhatian penuh atau memudahkan terhadap para pemohon pelayanan atau memberikan perhatian yang tulus tanpa pamrih terhadap para pemohon pelayanan.

Hasil penilaian responden sebagaimana tersaji dalam tabel III

\section{Tabel III}

Tabel Frekuensi Kualitas Pelayanan

Dimensi Emphaty (Empati)

$$
\mathrm{n}=30
$$

\begin{tabular}{|c|c|c|c|c|c|c|c|c|c|c|}
\hline \multirow{2}{*}{ No } & \multirow{2}{*}{ Indikator } & \multicolumn{5}{|c|}{ Penilaian } & \multirow{2}{*}{ Jumlah } & \multirow{2}{*}{$\begin{array}{l}\text { Rata- } \\
\text { rata }\end{array}$} & \multirow{2}{*}{$\%$} & \multirow{2}{*}{ Keterangan } \\
\hline & & 1 & 2 & 3 & 4 & 5 & & & & \\
\hline 1 & $\begin{array}{l}\text { Pimpinan instansi dan atau } \\
\text { pegawai yang memberikan } \\
\text { pelayanan kepada masyarakat } \\
\text { harus mudah dihubungi dangan } \\
\text { telefon dan mudah ditemui }\end{array}$ & 1 & 12 & 39 & 20 & 25 & 97 & 3.23 & 64.7 & $\begin{array}{c}\text { Cukup } \\
\text { Berkualitas }\end{array}$ \\
\hline
\end{tabular}


2 Instansi yang memberikan pelayanan kepada masyarakat membantu pemohon pelayanan tanpa pamrih atau tulus ikhlas karena kewajibannya

3 Prosedur atau proses pelayanan harus berjalan lancar, sehingga tidak menimbulkan antrian

4 Petugas mengerti keinginan pasien $\begin{array}{lllll}0 & 8 & 30 & 32 & 35\end{array}$ 105 $3.50 \quad 70.0$

Cukup Berkualitas

\begin{tabular}{lllllllllll}
\hline 4 & Petugas mengerti keinginan pasien & 0 & 10 & 27 & 44 & 20 & 101 & 3.37 & 67.3 & $\begin{array}{c}\text { Cukup } \\
\text { Berkualitas }\end{array}$ \\
\hline 5 & $\begin{array}{l}\text { Petugas harus memiliki } \\
\text { kemampuan komunikasi yang baik } \\
\text { dalam melayani pasien }\end{array}$ & 0 & 6 & 36 & 16 & 55 & 113 & 3.77 & 75.3 & Berkualitas \\
\hline 6 & $\begin{array}{l}\text { Memberikan informasi kepada } \\
\text { pasien apabila ada hal baru dalam } \\
\text { pelayanan kesehatan }\end{array}$ & 0 & 8 & 27 & 24 & 55 & 114 & 3.80 & 76.0 & Berkualitas \\
Nilai Rata-rata & & & & & & $\mathbf{3 . 4 9}$ & 69.9 & $\begin{array}{c}\text { Cukup } \\
\text { Berkualitas }\end{array}$ \\
\hline
\end{tabular}

Sumber: Hasil pengolahan data primer

Dari tabel diatas menunjukkan bahwa nilai rata-rata dimensi Emphaty (Empati) adalah 3.49. Ini menunjukkan bahwa hasil kuesioner menyatakan penilaian responden terhadap dimensi ini adalah cukup berkualitas, atau sebanyak 69.9\% responden menilai dimensi ini cukup berkualitas.

Adapun hasil wawancara mendalam (indepth interview) dengan responden internal RSUD dapat ditarik kesimpulan bahwa secara umum mereka menilai dimensi emphaty (empati) adalah berkualitas. Semua indikator pada dimensi ini dinilai berkualitas. mulai dari pimpinan instansi dan atau pegawai yang memberikan pelayanan kepada masyarakat harus mudah dihubungi dangan telefon dan mudah ditemui, instansi yang memberikan pelayanan kepada masyarakat membantu pemohon pelayanan tanpa pamrih atau tulus ikhlas karena kewajibannya, prosedur atau proses pelayanan harus berjalan lancar, sehingga tidak menimbulkan antrian, petugas mengerti keinginan pasien, petugas harus memiliki kemampuan komunikasi yang baik dalam melayani pasien dan memberikan informasi kepada pasien apabila ada hal baru dalam pelayanan kesehatan semuanya dinilai berkualitas.

Adapun hasil wawancara mendalam (indepth interview) dengan pasien/keluarga pasien sebagai informan kunci (key informan) yang berjumlah tujuh orang mengenai dimensi emphaty (empati) dapat disimpulkan bahwa penilaian dimensi emphaty (empati) adalah hampir sama dengan penilaian dari informan sebelumnya yaitu cukup berkualitas. Masalah yang masih ditemukan tetap pada antrian yang cukup lama pada loket pengambilan obat dan di ruang tunggu dokter. Penyebabnya hampir sama dengan penilaian dari informan sebelumnya yaitu kurangnya jumlah petugas yang ada dan kehadiran dokter yang sering terlambat. Terutama pada harihari tertentu yang jumlah pasiennya cukup banyak.

Dari hasil kuesioner dan wawancara mendalam (indepth-interview) terhadap para informan baik informan kunci (key informan) maupun informan dari internal RSUD Bangka Tengah dapat disimpulkan bahwa dimensi emphaty (empati) adalah cukup berkualitas. Sebagian besar indikator pada dimensi ini dinilai cukup berkualitas. Ada permasalahan yang harus dibenahi yaitu masalah antrian yang masih sering ditemukan, disebabkan kurangnya jumlah pegawai dan keterlambatan kehadiran dokter. Jadi secara umum mereka menilai cukup berkualitas, artinya instansi dan para petugas layanan pada Poliklinik Gigi dalam melayani msyarakat/pasien belum sesuai dengan Standar Pelayanan Minimal (SPM) yang ditetapkan oleh Menteri Kesehatan melalui Peraturan Menteri Kesehatan nomor 43 tahun 2016 serta Peraturan Bupati Bangka Tengah tentang Standar Pelayanan Minimal RSUD Bangka Tengah tahun 2017 dan Standar Operasional Prosedur (SOP) RSUD Bangka Tengah itu sendiri.

Dari uraian diatas dapat disimpulkan sebagaimana tabel rekapitulasi dibawah ini: 
Tabel IV

Rekapitulasi Tabel Frekuensi Kualitas Pelayanan

\begin{tabular}{clcl}
\hline No & Dimensi & Kategori Nilai & Keterangan \\
\hline 1 & Responsivenes & Cukup Berkualitas & Sebanyak 69.8\% rsponden menilai dimensi ini cukup berkualitas \\
\hline 2 & Assurance & Berkualitas & Sebanyak 76\% rsponden menilai dimensi ini cukup berkualitas \\
\hline 3 & Emphaty & Cukup Berkualitas & Sebanyak 69.9\% rsponden menilai dimensi ini cukup berkualitas \\
\hline
\end{tabular}

Sumber: Hasil pengolahan data primer

Hasil kuesioner diatas diperkuat dengan hasil wawancara mendalam (indeptinterview) yang dilakukan terhadap beberapa informan, baik yang berasal dari internal RSUD Bangka Tengah maupun informan berasal dari masyarakat sebagai pengguna pelayanan tersebut.

\section{KESIMPULAN DAN SARAN}

\section{A. Kesimpulan}

Berdasarkan hasil analisis dan pembahasan mengenai kualitas pelayanan publik di Poliklinik Gigi RSUD Bangka Tengah maka dapat disimpulkan bahwa penilaian masyarakat sebagai pengguna pelayanan publik menyatakan bahwa dimensi Responsiveness (ketanggapan) dinilai cukup berkualitas, Sebagian besar informan kunci (key informan) menilai dimensi ini cukup berkualitas dan sebagian kecil menilai tidak berkualitas terutama pada indikator ketanggapan dan kecepatan petugas dalam melayani pasien dirasakan masih perlu ditingkatkan. Dalam arti kata belum sesuai dengan Standar Pelayanan Minimal yang ditetapkan oleh Menteri Kesehatan melalui Peraturan Menteri Kesehatan nomor 43 tahun 2016 serta Peraturan Bupati Bangka Tengah tentang Standar Pelayanan Minimal (SPM) RSUD Bangka Tengah tahun 2017 dan Standar Operasional Prosedur (SOP) yang ada. Namun secara umum atau rata-rata masyarakat menilai dimensi ini cukup berkualitas.

Dimensi Assurance (jaminan) dinilai berkualitas, terutama yang berkaitan dengan indikator tentang jaminan tidak ada pungutan liar, dimana para informan menilai bahwa instansi RSUD bangka Tengah khususnya dibagian Poliklinik Gigi tidak menemukan adanya pungutan liar. Artinya instansi ini telah menerapkan peraturan presiden nomor 87 tentang Satuan Tugas Sapu Bersih Pungutan Liar. Selain itu instansi dan para petugas telah melaksanakan Standar Pelayanan Minimal yang ditetapkan oleh Menteri Kesehatan melalui Peraturan Menteri Kesehatan nomor 43 tahun 2016 serta Peraturan Bupati Bangka Tengah tentang Standar Pelayanan Minimal RSUD Bangka Tengah tahun 2017 dan Standar Operasional Prosedur (SOP) RSUD Bangka Tengah.

Adapun dimensi Emphaty (empati) dinilai cukup berkualitas. Sebagian besar indikator pada dimensi ini dinilai cukup berkualitas. Ada permasalahan yang harus dibenahi dalam dimensi ini yaitu masalah antrian yang masih sering ditemukan, disebabkan kurangnya jumlah pegawai dan keterlambatan kehadiran dokter. Jadi secara umum atau rata-rata mereka menilai cukup berkualitas, artinya instansi dan para petugas layanan pada Poliklinik Gigi dalam melayani msyarakat/pasien belum sesuai dengan Standar Pelayanan Minimal (SPM) yang ditetapkan oleh Menteri Kesehatan melalui Peraturan Menteri Kesehatan nomor 43 tahun 2016 serta Peraturan Bupati Bangka Tengah tentang Standar Pelayanan Minimal RSUD Bangka Tengah tahun 2017 dan Standar Operasional Prosedur (SOP) RSUD Bangka Tengah itu sendiri.

Untuk lebih jelasnya hasil penilaian dari para informan tentang kualitas pelayanan publik di Poliklinik Gigi pada Instalasi Rawat Jalan RSUD Bangka Tengah dapat dilihat pada 
tabel V dibawah ini:

\section{Tabel V}

Hasil penilaian informan terhadap kualitas pelayanan publik di Poliklinik Gigi RSUD Bangka Tengah.

\begin{tabular}{clc}
\hline No & \multicolumn{1}{c}{ Dimensi Servqual } & Kategori Nilai \\
\hline 3 & Responsivenes (ketanggapan) & Cukup Berkualitas \\
\hline 4 & Assurance (jaminan) & Berkualitas \\
\hline 5 & Emphaty (empati) & Cukup Berkualitas \\
\hline
\end{tabular}

Sumber: Hasil pengolahan Data

Ada Beberapa temuan permasalahan yang menyebabkan penilaian kurang maksimal dan perlu mendapatkan perhatian untuk ditingkatkan yaitu:

1. Kurangnya sarana operasional pelayanan Poliklinik Gigi

2. Kurangnya SDM yang terkait dengan pelayanan pada Poliklinik Gigi seperti Dokter Spesialis Gigi dan Perawat Gigi.

3. Persyaratan administrasi yang belum memudahkan pasien.

4. Masih sering dijumpai antrian yang lama dalam proses pelayanan terutama di ruang tunggu dan loket pengambilan obat.

\section{B. Saran}

Setelah mengetahui hasil analisis seperti yang telah dijelaskan diatas maka saran-saran yang bisa diberikan untuk peningkatan kualitas pelayanan RSUD Bangka Tengah khususnya di bagian Poliklinik Gigi dimasa yang akan datang adalah sebagai berikut:

1. Perlu menambah jumlah pegawai terutama Dokter Spesialis Gigi dan apoteker, hal ini merupakan salah satu cara untuk menghindari antrian yang lama, karena yang menjadi faktor penyebab terjadinya antrian yang panjang adalah jumlah petugas yang sedikit, sementara jumlah pengunjung cukup banyak.

2. Perlu meningkatkan kemampuan petugas pelayanan kepada masyarakat dalam hal tampil rapi, menarik dan ramah dengan memberikan pelatihan terkait dengan pelayanan prima.

3. Perlu meningkatkan disiplin pegawai terutama masalah kehadiran tepat waktu sehingga masyarakat/pasien tidak menunggu terlalu lama.

Demikian saran-saran yang bisa direkomendasikan, semoga kualitas pelayanan di RSUD Bangka Tengah khususnya di Poliklinik Gigi kedepannya semakin meningkat yang pada akhirnya akan meningkatkan kesejahteraan masyarakat terutama dalam bidang kesehatan karena masyarakat yang sehat merupakan salah satu kunci kemajuan bangsa. 


\section{DAFTAR PUSTAKA}

Bungin, B. (2011). Metodologi penelitian kuantitatif: komunikasi, ekonomi, dan kebijakan publik, serta ilmuilmu social lainnya. Edisi Kedua. Jakarta: Prenada Media Group.

Dwiyanto, Agus. (2005). Mewujudkan Good Governance Melalui Pelayanan Publik. Yogyakarta: Gajah Mada University Press.

Hardiansyah. (2011). Kualitas Pelayanan Publik. Yogyakarta: Gaya Media.

Handayaningrat, Soewarno. (1996). Pengantar Studi Ilmu Administrasi dan Manajemen. Jakarta: Guning Agung.

Jurnal Ilmiah Administrasi Publik, (2018), JIAP Vol 4, No 4, pp 331-342.

Jurnal Administrasi Publik, Vol 6, No 2 (2016): Desember, page. 129-141. Publisher: Universitas Medan Area

Kotler, Philip. (2003). Marketing Management. New Jersey: Prentice Hall.

Koentjaraningrat dan D. K. Emmerson. (1985). Aspek Manusia dalam Penelitian Masyarakat. Jakarta: PT Gramedia.

Maruti, Sri K. (2013). Resvonsivitas Pelayanan Kantor Pertanahan Kota Salatiga Dalam Implemen Program LARASITA. Surakarta: Tugas Akhir Program Magister, Magister Administrasi Publik Universitas Sebelas Maret Surakarta.

Moenir, A.S. (2008). Manajemen pelayanan Umum di Indonesia. Jakarta: Bina Aksara.

Moleong, Lexy J. (2002). MetodologiPenelitian Kualitatif. Bandung: Remaja Rosdakarya.

Parasuraman, A., Zeithami, V. dan Berry L. (1988). SERVQUAL: A Multiple item Scale for Measuring Consumer Perceptions of Service Quality. Journal of Retaliling.

Ratminto dan Atik Septi Winarsih (2006). Manajemen Pelayanan. Yogyakarta: Pustaka Pelajar

Rencana Strategis RSUD Bangka Tengah Tahun 2017

Sinambela, Lijan Poltak, dkk. (2006). Reformasi Pelayanan Publik. Jakarta: Bumi Aksara.

Standar Pelayanan Minimal RSUD Bangka Tengah Tahun 2017

Sugiono. (2012). Metode Penelitian Bisnis. Bandung: Alfabeta

Sumaryadi, I Nyoman. (2010). Sosiologi Pemerintahan (Dari Perspekstif Pelayanan, Pemberdayaan, Interaksi, dan Sistem Kepemimpinan Pemerintahan Indonesia). Bogor: Ghalia Indonesia.

Tjiptono, Fandy. (2004) Prinsip-Prinsip Total Quality Service (TQS). Yogyakarta: Andi Offset.

Tjiptono, Fandy dan Gregorius Candra. (2005). Service, Quality, and Satisfaction. Yogyakarta: Andi Offset.

Toha. Miftah. 2007. Perilaku Oganisasi Konsep Dasar dan Aplikasinya. Jakarta:

Pt Raja Grafindo Persada.

Undang-Undang Nomor 25 Tahun 2009 Tentang Pelayanan Publik

Uma, Sekaran. (2006). Metode Penelitian Bisnis. Jakarta: Salemba Empat. 
Peraturan Presiden Republik Indonesia Nomor 87 Tahun 2016 Tentang Satuan Tugas Sapu Bersih Pungutan Liar

Peraturan Menteri Kesehatan Nomor 43 tahun 2016 tentang Standar Pelayanan Minimal bidang kesehatan

Peraturan Bupati Bangka Tengah Tentang Standar Pelayanan Minimal Rumah Sakit Tahun 2017.

Profile RSUD Bangka Tengah Tahun 2017

Wahab, Solichin. (2008). Pengantar Kebijakan Publik. Malang: UMM PRESS.

Walgito, Bimo. (2002). Pengantar Psikologi Umum. Yogyakarta: Andi Offset.

Winardi, J. (2003). Teori Organisasi dan Pengorganisasian. Jakarta: PT. Raja Grafindo Persada

Winarno, Budi. (2007). Teori dan Proses Kebijakan Publik. Yogyakarta: Media Pressindo.

Widodo, Joko. (2007). Analisis kebijakan publik. Malang: Bayumedia Publishing.

Wiryatmi, Endang. (2001). Filofofi, Stratgi dan Teknik Pelayanan Prima di Sektor Publik; disususn dalam rangka Ceramah tentang Manajemen Pelayanan Prima di Lembaga Administrasi Negara Bandung Tanggal 89 Agustus 2001. 